\title{
Ruptured true superficial femoral artery aneurysm
}

\section{Aneurisma verdadeiro roto de artéria femoral superficial}

Ani Loize Arendt', Robinson de Menezes do Amaral' ${ }^{1}$, Mariana Sesterhenn Vieira', Rafael de Nogueira Ribeiro', Rodrigo Argenta ${ }^{1}$

\begin{abstract}
Femoral artery aneurysms are rare and generally affect elderly patients. They are often diagnosed in combination with aneurysms in other locations, such as peripheral and aortic aneurysms. This case report describes a young patient whose superficial femoral artery (SFA) had a clinical presentation suggestive of a ruptured aneurysm. The patient underwent standard treatment, with aneurysmectomy and interposition of the ipsilateral saphenous vein. A review of the literature confirms the rarity of this case.
\end{abstract}

Keywords: superficial femoral artery; ruptured aneurysm.

\section{Resumo}

Os aneurismas de artéria femoral são raros e ocorrem geralmente em pacientes idosos. Estão frequentemente associados a outros aneurismas, tanto periféricos como de aorta abdominal. O presente relato refere-se a um jovem portador de aneurisma de artéria femoral superficial (AFS), cuja apresentação clínica foi a ruptura. O paciente foi submetido ao tratamento convencional, com ressecção do aneurisma e interposição de veia safena magna ipsilateral. A revisão da literatura corrobora a raridade do caso.

Palavras-chave: artéria femoral superficial; aneurisma roto. 


\section{INTRODUCTION}

Degenerative, isolated, true aneurysms of the superficial femoral artery (SFA) are rare and probably only account for $1 \%$ of all femoral artery aneurysms ${ }^{1}$ and $0.5 \%$ of peripheral aneurysms ${ }^{2}$.

Aneurysms of the SFA are normally an incidental finding, but they can also present in combination with distal ischemia, a pulsating mass in the thigh or a painful and pulsating mass, if they rupture or there is hemorrhaging ${ }^{3}$.

Complications including thrombosis ${ }^{1,2,4}$, distal embolization $^{1,4}$ or rupture ${ }^{1,2,4}$ can occur, but are less frequent than in patients with popliteal artery aneurysms ${ }^{1}$. The incidence of complications suggests that resection and revascularization should be elective, while investigation is mandatory for peripheral aneurysms and aortoiliac aneurysms ${ }^{3}$.

This case report presents the treatment and outcome of a ruptured SFA aneurysm in a young patient with no diagnosed etiology, and provides a brief review of the relevant literature.

\section{CASE HISTORY}

The patient was a 27-year-old, black, male student from the Brazilian city of Porto Alegre. He did not take injectable drugs, but was a smoker and user of cocaine and marijuana. There was no history of previous traumas, surgery or chronic degenerative diseases.

The patient sought emergency hospital treatment for sudden pain and progressive swelling of the left thigh.

On presentation the patient had no fever and had normal blood pressure $(120 / 80 \mathrm{mmHg})$. Cardiac auscultation findings were normal, with a regular 82 bpm heartbeat. Pulmonary auscultation revealed uniformly distributed vesicle murmurs. An abdominal examination found nothing unusual.

Right lower limb pulses were normal (2) at the groin (femoral), popliteal and distal (pedal and posterior tibial pulses) regions. The left lower limb femoral pulse was normal (2) and the popliteal and distal pulses were subdued (1), but present. There was a large pulsating mass in the mid third of the left thigh (Figure 1).

There were no significant blood test abnormalities and electrolytes and renal function tests were normal.

Emergency color Doppler ultrasound of the artery revealed an image with a greatest diameter of 6.0 $\mathrm{cm}$ within the topography of the mid third of the superficial femoral artery, with turbulent interior flow, poorly-defined limits and mural thrombus.

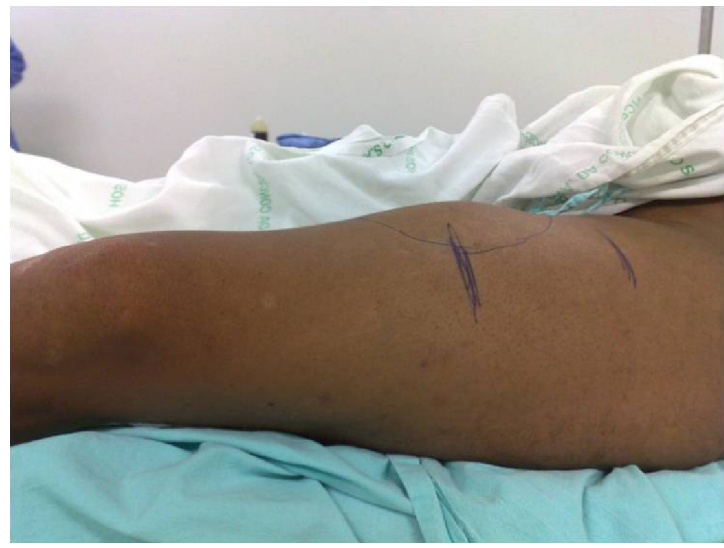

Figure 1. Mass in the mid third of the left thigh.

These characteristics suggested a ruptured aneurysm of the superficial femoral artery.

Arteriography showed that the abdominal and iliac aortas were patent, with no significant obstructions, and that the mid segment of the right superficial femoral artery was dilated. The distal segment showed signs of compression by the adjacent mass and the distal superficial femoral and popliteal arteries had flow, primarily originating in collateral branches (Figures 2, 3 and 4).

The patient underwent exploratory surgery of the left lower limb. There was a large-volume hematoma related to the ruptured aneurysm of the left superficial femoral artery (Figure 5).

The aneurysm was resected and the vascular segment reconstructed by reversed interposition of a segment of the ipsilateral saphenous vein (Figure 6). The surgical technique employed was continuous sutures at the arterial anastomoses using 6.0 polypropylene thread. The muscle planes were drawn together using continuous 3.0 nylon thread sutures and skin was sutured with separated 4.0 nylon thread sutures.

During the postoperative period, the patient suffered hematoma of the surgical wound and an infection, requiring a second intervention for drainage and surgical debridement, which increased the length of hospital stay and the morbidity related to the procedure. The patient was discharged from hospital 19 days after the first surgery.

The patient underwent transesophageal echocardiogram during the postoperative period, with normal results. Fragments of tissue removed during the first operation were sent for microscopic examination and bacteriological tests; but no germ growth was detected. The patient was subjected to rheumatologic tests and the results were negative. 

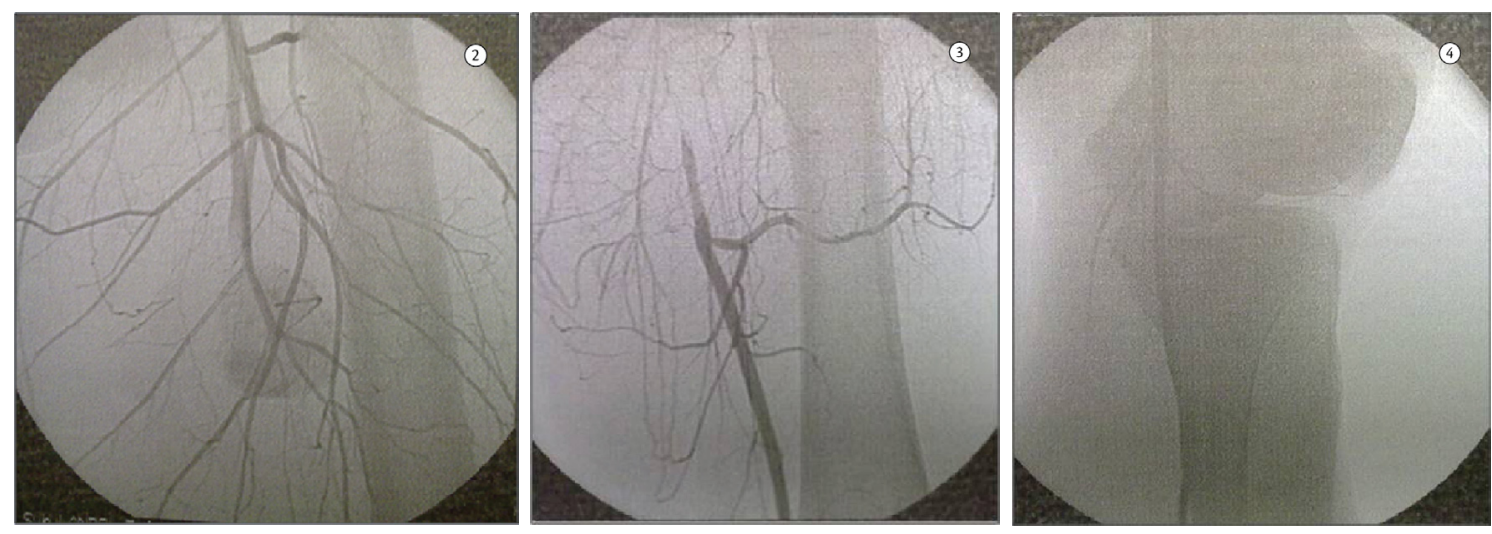

Figures 2, 3 and 4. Arteriography. Aneurysm of mid segment of the SFA with occlusion below and reinhabitation of the distal superficial femoral artery and the popliteal artery by collateral circulation.

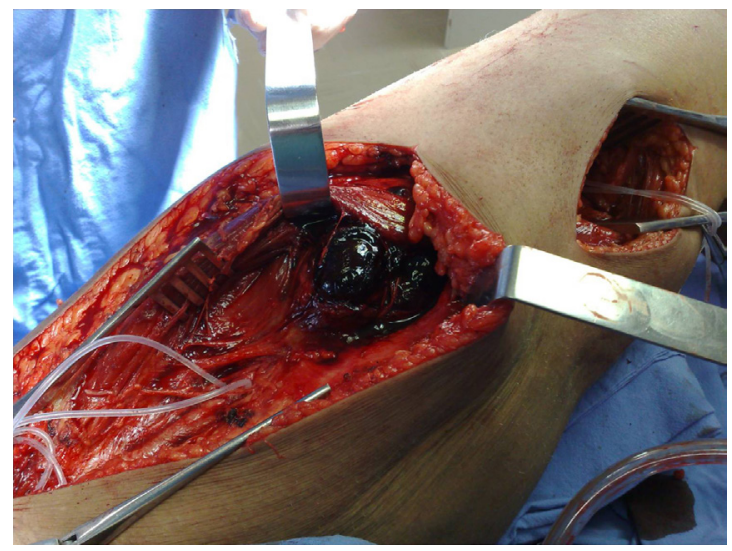

Figure 5. Surgical procedure, showing large volume hematoma with ruptured SFA aneurysm.

\section{DISCUSSION}

Aneurysms of the superficial femoral artery are rare $^{1,2,4-9}$ and tend to affect the elderly population, predominantly men ${ }^{1,7}$. In $18 \%$ of cases they are bilateral $^{8}$. They are generally not diagnosed until complications occur ${ }^{7}$. It is believed that SFA aneurysms and their complications are less common because of the superficial femoral artery's location within Hunter's canal?

Superficial femoral artery aneurysms are associated with aneurysms in other locations in $27-69 \%$ of cases $^{8}$. The incidence of concurrent abdominal aortic aneurysms can reach $40 \%{ }^{7}$. Aneurysms of peripheral arteries can be associated with etiologic factors such as syphilis; immunological disorders ${ }^{7}$, such as Behçet's disease ${ }^{10}$; inflammatory conditions ${ }^{7}$, such as Wegener's granulomatosis ${ }^{11}$; connective tissue disorders, such as the Ehlers- Danlos syndrome ${ }^{7}$ or Marfan's syndrome ${ }^{4,7}$, or with secondary factors such as fibrodysplasia ${ }^{12}$ or malignancies ${ }^{4}$.

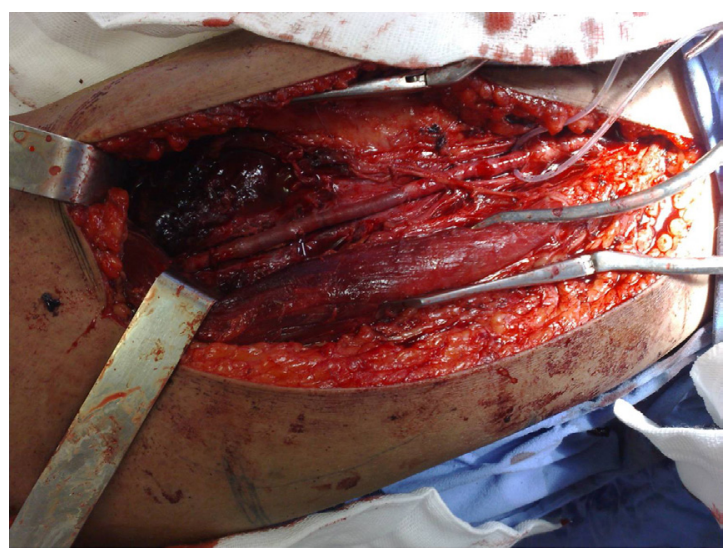

Figure 6. Aneurysmectomy of SFA and revascularization with reverse saphenous in end-to-end anastomosis.

Since elective surgery is associated with lower morbidity and mortality, it is of extreme importance to achieve early diagnosis ${ }^{1}$. Diagnosis is based on angiotomography, magnetic resonance angiography and vascular Doppler ultrasonography, which make it possible to visualize the aneurysm's anatomic relationships and can also be used to plan surgery ${ }^{13-15}$. Nevertheless, arteriography still has its place, primarily for investigation of the distal bed for planning revascularization ${ }^{15}$.

Complications, such as thrombosis, distal embolization or rupture ${ }^{1,4}$, can occur, but they are less common than is seen with patients with popliteal artery aneurysms ${ }^{1}$. A study conducted by Jarrett et al. described 13 patients with aneurysms of the superficial femoral artery, 76\% of whom presented with critical ischemia of a lower limb or a painful mass ${ }^{9}$. The authors of a review of 14 studies covering 38 aneurysms estimated that incidence rates of rupture and thrombosis were $34 \%$ and $26 \%$ 
respectively and other aneurysms were also present in $39 \%$ of cases ${ }^{1}$. In view of this, aneurysms that are symptomatic or are larger than $2.5 \mathrm{~cm}$ must be repaired in order to avoid complications that could put the limb's viability at risk ${ }^{16}$.

Conventional open surgery is currently still the gold standard for peripheral aneurysms ${ }^{16,17}$, with end-to-end anastomosis ${ }^{1}$, vein grafts or prostheses ${ }^{1}$. With focal aneurysms, the aneurysm sac is opened, with evacuation of the thrombus, and an end-to-end anastomosis is performed ${ }^{1}$. Endoaneurysmorrhaphy and interposition of autologous or heterologous grafts are recommended ${ }^{18}$ for more extensive aneurysms ${ }^{1}$. While conventional treatment with femoropopliteal revascularization, preferably using an autologous vein, has achieved excellent results, there are also other techniques that can be employed ${ }^{2}$. Placement of endoprostheses has also been described as an alternative treatment option for aneurysms ${ }^{17}$. When patients do not have the clinical conditions for open surgery and particularly for the elderly, percutaneous treatment of SFA aneurysms can be performed with acceptable results ${ }^{19}$. Another treatment option could be simple ligature of the artery, primarily in cases where the patient has compensation of peripheral arterial occlusive disease ${ }^{20}$.

The results of surgical treatment are similar to what is seen after femoropopliteal revascularization. When surgery is elective, 2-year venous graft patency rates are approximately $80 \%$, compared to $65 \%$ when using PTFE grafts ${ }^{1}$.

This case report described conventional treatment for superficial femoral artery aneurysm. While, on the one hand, choosing open surgery offers the benefit of durability, it also involves a risk of complications due to the surgery itself. The hematoma and infection that affected this patient were serious complications and extended the length of his hospital stay considerably. These factors should always be taken into consideration when choosing the treatment option, bearing in mind that endovascular treatment is of relatively easy access in our setting.

\section{CONCLUSIONS}

Superficial femoral artery aneurysms are rare and their presentation with rupture is even more rare. Clinical suspicion should always be aroused when faced with a pulsating tumor in the thigh. Treatment with open surgery appears to be a good option, particularly for younger patients.

\section{REFERENCES}

1. utherford RB. Superficial Femoral Artery Aneurysm. In: Rutherford RB, editor. Vascular Surgery. Philadelphia: WB Sauders; 2005. p. 1538-39.

2. Oliveira FA, Oliveira HO Fo. Aneurisma de artéria femoral superficial roto: relato de caso e revisão de literatura. J Vasc Bras. 2009;8(3):285-8. http://dx.doi.org/10.1590/ S1677-54492009000300019

3. Jarrett F, Makaroun MS, Rhee RY, Bertges DJ. Superficial femoral artery aneurysms: An unsusual entity? J Vasc Surg. 2002;36(3):5714. PMid:12218983. http://dx.doi.org/10.1067/mva.2002.125841

4. Vilariño-Rico J, Vidal-Insua JJ, Cachaldora já, Segura-Iglesias RJ. Aneurismas verdaderos de la femoral superficial: a propósito de un caso. Angiol (Barcelona). 2008;60(2):149-54. http://dx.doi. org/10.1016/S0003-3170(08)02011-7

5. Dobritz M, Lang W, Fellner FA. MR diagnosis of superficial femoral artery aneurysm, primarily misdiagnosed as soft tissue tumor. A case report. Magn Res Imag. 2003;21:687-90. http://dx.doi. org/10.1016/S0730-725X(03)00086-9

6. Duhaldes IS, Berga CF, Arrebola ML, et al. Aneurisma de arteria femoral superficial: reporte de un caso y revisión de la patología. Cuad Cir. 2004;18(1):48-51. http://dx.doi.org/10.4206/cuad. cir.2004.v18n1-08

7. Hatrick AG, Malcolm PN, Burnand KG, Irvine AT. A Superficial Femoral Artery Aneurysm in a Patient with Marfan's Syndrome. Eur J Vasc Endovasc Surg. 1998;15:459-60. http://dx.doi. org/10.1016/S1078-5884(98)80212-8

8. Papadoulas S, Skroubis G, Marangos MN, Kakkos SK, Tsolakis JA. Ruptured Aneurysms of Superficial Femoral Artery. Eur J Vasc Endovasc Surg. 2000;19:430-2. PMid:10801380. http://dx.doi. org/10.1053/ejvs.1999.0986

9. Siani A, Flaishman I, Napoli F, Schioppa A, Zaccaria A. Rupture of an isolated true superficial femoral artery aneurysm: case report. G Chir. 2005;26(5):215-7. PMid:16184706.

10. Carmona-Berriguete S, López-Quero D, Martín-Álvarez A, et al. Aneurisma femoral bilateral en síndrome de Behcet: a propósito de un caso. Angiol (Barcelona). 2008;60(2):155-9. http://dx.doi. org/10.1016/S0003-3170(08)02012-9

11. Luebke T, Aleksis $M$, Bunkwall J. Superficial femoral artery aneurysm: a rare complication of wegener granulomatosis. Vasc. 2009;17(4):213-7. http://dx.doi.org/10.2310/6670.2009.00016

12. Giordanengo F, Beretta L, Galimberti M, Ferrero S. A rare case of aneurysm of the superficial femoral artery with dysplasic etiology. Minerva Chir. 1989;44(7):1173-7. PMid:2664565.

13. Bonelli U, Cerruti R, Arnuzzo L. Aneurysms of the superficia femoral artery at the rupture stage. Apropos 2 personal cases. Minerva Chir. 1991;46(19):1071-3. PMid:1771029.

14. Guégan H, Carles J, Janvier G, Videau J. Compressive thigh hematoma. Apropos of a case of fissured superficial femoral aneurysm in megadolicho-arteries. J Chir (Paris). 1991;128(5):247-50

15. Leon LR Jr, Taylor Z, Psalms SB, Mills JL. Degenerative Aneurysms of the Superficial Femoral Artery. Eur J Vasc Endovasc Surg. 2008;35:332-40. PMid:17988902. http://dx.doi.org/10.1016/j. ejvs.2007.09.018

16. Corriere MA, Guzman RJ. True and False Aneurysms of the Femora Artery. Semin Vasc Surg. 2005;18(4):216-23. PMid:16360579. http://dx.doi.org/10.1053/j.semvascsurg.2005.09.008

17. Müller-Hülsbeck S, Link J, Schwarzenberg $\mathrm{H}$, Walluscheck KP, Regensburger D, Heller M. Minimal invasive therapy of aneurysms 
of the superficial femoral arteru and the popliteal artery. Zentralb| Chir. 1997;122(9):775-80. PMid:9454487.

18. Celi S, Mandolfino T, Micali C, Castiglione N. Aneurysm of the superficial femoral artery. Chir Ital. 1984;36(2):260-5. PMid:6525690.

19. Michel C, Laffy PY, Leblanc G, et al. Traitement percutané d'un anévrisme de l'artère fèmorale superficielle par endoprothèse couverte. J Radiol. 1999;80:473-6. PMid:10372327.

20. Dighe $S$, Thomas P. Ruptured superficial femoral artery aneurysm treated by simple ligation. Singapore Med J. 2008;49(6):151-2.
Correspondence

Ani Loize Arendt

Hospital Nossa Senhora da Conceição (HNSC) Rua Gaston Englert, 675/160

CEP 91360-210 - Porto Alegre (RS), Brazil Fone: +55 (51) 98216461 E-mail: alarendt@gmail.com

Author's information

ALA is a resident physician of vascular surgery at Hospital Nossa Senhora da Conceição (HNSC). RM, MSV, and RNR are vascular surgeons at Hospital Nossa Senhora da Conceição (HNSC)

RA is in charge of the Vascular Surgery Residency Program at Hospital Nossa Senhora da Conceição (HNSC) and holds a MSc degree in surgery from the School of Medicine of Universidade Federal do Rio Grande do Sul (FAMED-UFRGS).

Author's contributions Conception and design: ALA, RMA, RA Analysis and interpretation: ALA, RA Data collection: ALA, RMA, MSV Writing the article: ALA, RA Critical revision of the article: RMA, MSV, RNR, RA Final approval of the article*: ALA, RMA, MSV, RNR, RA Statistical analysis: N/A Overall responsibility: ALA Obtained funding: None.

*All authors should have read and approved of the final version of the article submitted to I Vasc Bras. 